\title{
Tailored Dealloying Products of Cu-based Metallic Glasses in Hydrochloric Acid Solutions
}

\author{
Zhifeng Wang, Lijuan Wang, Chunling Qin*, Jiangyun Liu, Yongyan Li, Weimin Zhao
}

\author{
School of Materials Science and Engineering, Hebei University of Technology, Tianjin 300130, China
}

Received: January 15, 2014; Revised: April 2, 2014

\begin{abstract}
Free dealloying of $\mathrm{Cu}-\mathrm{Hf}-\mathrm{Al}$ metallic glasses in $\mathrm{HCl}$ electrolytes are studied in this paper. The results show that the electrolyte concentration and dealloying time strongly influence the type of dealloying products. A superficial dealloying happens in diluted $\mathrm{HCl}$ electrolytes while a complete dealloying occurs in concentrated $\mathrm{HCl}$ electrolytes. The results present that $\mathrm{Cu}_{2} \mathrm{O}$ microparticles with regular morphology can be tailored on glassy surfaces in $0.05 \mathrm{M} \mathrm{HCl}$ solution by controlling the dealloying time. Furthermore, the designable products of nanoporous $\mathrm{Cu}, \mathrm{Cu}_{2} \mathrm{O}$ nanoplates and $\mathrm{CuO}$ microwires can be fabricated in $1.2 \mathrm{M} \mathrm{HCl}$ electrolyte with the dealloying time. Due to a big difference of examined $\mathrm{Cu}-\mathrm{Hf}-\mathrm{Al}$ alloys in the electrolyte concentration and dealloying time, one or mixed dealloying products $\left(\mathrm{Cu}, \mathrm{Cu}_{2} \mathrm{O}\right.$ and $\left.\mathrm{CuO}\right)$, which depend on the progress of relative chemical reactions and the different dealloying route, will finally be produced.
\end{abstract}

Keywords: Metallic glass, dealloying, corrosion products, hydrochloric acid

\section{Introduction}

Dealloying, or selective removal of one or more components from a binary or multicomponent alloy, has become a popular technique for rapid and direct generation of various nanoporous metals and alloys recently ${ }^{1-4}$. Nanoporous metals produced by dealloying have been applied in many fields, such us catalysis ${ }^{5}$, heat exchangers ${ }^{6}$, actuators ${ }^{7}$, energy storage $\mathrm{e}^{2,8}$, fuel cells ${ }^{9}$, sensors ${ }^{10}$ and radiation damage resistant materials ${ }^{11}$. Moreover, dealloying process can be extended to the fabrication of important transition metal oxide nanostructures with intricate structural properties rather than a porous structure as often seen during dealloying ${ }^{12}$. For instance, regular $\mathrm{Fe}_{3} \mathrm{O}_{4}$ octahedra, $\mathrm{Co}_{3} \mathrm{O}_{4}$ nanoplates and octahedral-like $\mathrm{Mn}_{3} \mathrm{O}_{4}$ nanoparticles have been successfully produced by the in situ dealloying and spontaneous oxidation method ${ }^{13,14}$. Nowadays, not only nanoporous metals but also transition metal oxide can be fabricated by dealloying and extended methods.

Usually, the formation of a porous structure during dealloying in electrolytes needs to address some issues including the critical potential, the dealloying threshold, the initial alloy composition and so on ${ }^{15}$. Furthermore, Chen ${ }^{16}$ found that a critical concentration of electrolytes required for the formation of nanoporosity. For example, nanoporous $\mathrm{Cu}$ (NPC) with different pore characteristics are able to be fabricated by electrochemically dealloying $\mathrm{Cu}_{30} \mathrm{Mn}_{70}$ alloy in $0.025 \mathrm{M}, 0.1 \mathrm{M}$ and $0.5 \mathrm{M} \mathrm{HCl}$ electrolytes with different time. Instead of the formation of NPC, however, nanostructured cuprous oxide $\left(\mathrm{Cu}_{2} \mathrm{O}\right)$ is made on the ribbon surfaces when electrochemically dealloying of the same alloy in $0.001 \mathrm{M} \mathrm{HCl}$ solution. Therefore, we can see that the electrolytes concentration is one of the key factors to determine which kind of dealloying products can be created during the dealloying.

*e-mail: chunlingqin@163.com; clqin@ hebut.edu.cn
Up to now, lots of literatures have focused on the fabrication of nanoporous $\mathrm{Cu}$ by dealloying different precursors in $\mathrm{HCl}$ solutions ${ }^{17-19}$. Unfortunately, few studies focused on the other dealloying products obtained from these precursors in $\mathrm{HCl}$ solutions ${ }^{20,21}$. In this paper, in order to systematically investigate the correlation between the dealloying products and the dealloying conditions, free dealloying of $\mathrm{Cu}-\mathrm{Hf}-\mathrm{Al}$ metallic glasses in both diluted and concentrated $\mathrm{HCl}$ electrolytes for different time are carried out. Various dealloying products, including $\mathrm{NPC}, \mathrm{Cu}_{2} \mathrm{O}$, and $\mathrm{CuO}$ with interesting morphologies, are produced and tailored by controlling the dealloying conditions. The indepth understanding the chemical process during dealloying is discussed in this work, which guides for designing different useful dealloying products.

\section{Experimental}

Ternary alloys with nominal compositions of $\mathrm{Cu}_{52.5} \mathrm{Hf}_{40} \mathrm{Al}_{7.5}$ (at.\%) were prepared by arc melting a mixture of pure $\mathrm{Cu}$ (99.99 wt.\%), pure Hf (99.99 wt.\%) and pure Al (99.99 wt.\%) in a high-purity argon gas atmosphere and using Ti getters. The melt spinning method was used to prepare amorphous $\mathrm{Cu}-\mathrm{Hf}-\mathrm{Al}$ ribbons with $20 \mu \mathrm{m}$ in thickness and $2 \mathrm{~mm}$ in width.

Dealloying was performed in hydrochloric acid $(\mathrm{HCl})$ solutions with a concentration of $0.05 \mathrm{M}$ and $1.2 \mathrm{M}$ in a free corrosion condition open to air at $298 \mathrm{~K}$. After different immersion times, the dealloyed ribbons were taken out and well rinsed with deionized water for three times to remove the residual chemical reagents and then dried in a vacuum drying oven before a further testing.

The amorphicity of the as-spun $\mathrm{Cu}-\mathrm{Hf}-\mathrm{Al}$ sample and phase type of the dealloyed specimens were confirmed by X-ray diffractometer (XRD, Bruker D8) with $\mathrm{Cu} \mathrm{K} \alpha$ 
radiation $(\lambda=0.15418 \mathrm{~nm})$. The morphology of the asdealloyed samples was observed by scanning electron microscope (SEM, Hitachi S-4800). The volume fraction of the dealloying products, which means the surface coverage rate of the corrosion products (such as $\mathrm{Cu}_{2} \mathrm{O}$ and $\mathrm{CuO}$ particles), is measured by the software Image Tool.

\section{Results and Discussion}

\subsection{Dealloying in $0.05 \mathrm{M} \mathrm{HCl}$ solution}

Figure 1 shows SEM images of the $\mathrm{Cu}_{52.5} \mathrm{Hf}_{40} \mathrm{Al}_{7.5}$ metallic glasses dealloyed in $0.05 \mathrm{M}$ diluted $\mathrm{HCl}$ solution at $298 \mathrm{~K}$ for different time. Regular $\mathrm{Cu}_{2} \mathrm{O}$ particles identified by XRD and energy-dispersive spectroscopy analysis ${ }^{20,21}$ with various shapes are formed on the surfaces of glassy alloys. With the increase of the dealloying time, $\mathrm{Cu}_{2} \mathrm{O}$ crystals with shapes of truncated tetrahedron ( $4 \mathrm{~h}$, Figure 1a), cube ( $5 \mathrm{~h}$, Figure $1 b)$, cuboctahedron $(6 \mathrm{~h})^{20}$, elongated cuboctahedron $(7 \mathrm{~h}$, Figure $1 \mathrm{c})$, truncated octahedron $(8 \mathrm{~h})^{20}$, octahedron (14 h, Figure $1 \mathrm{~d})$, hexapods $(20 \mathrm{~h})$ and dendrite $(24 \mathrm{~h})^{20}$ are observed on the ribbon surfaces. It is the first systematic work to synthesize $\mathrm{Cu}_{2} \mathrm{O}$ crystals with various shapes successfully by dealloying method. As a result, regular $\mathrm{Cu}_{2} \mathrm{O}$ microparticles with designable morphology can be tailored in diluted $\mathrm{HCl}$ solutions by controlling dealloying time.

Characteristics including morphology, size and volume fraction of $\mathrm{Cu}_{2} \mathrm{O}$ crystals produced by free dealloying of $\mathrm{Cu}_{52.5} \mathrm{Hf}_{40} \mathrm{Al}_{7.5}$ glassy alloys in $0.05 \mathrm{M} \mathrm{HCl}$ solution for different time open to air at $298 \mathrm{~K}$ are summarized in Table 1. From the Table 1, it can be seen that the threedimensional sizes of $\mathrm{Cu}_{2} \mathrm{O}$ crystals do not change much in the first 8 hours of dealloying though they show different edge length. Then, the sizes of $\mathrm{Cu}_{2} \mathrm{O}$ crystals increase obviously after dealloying for $14 \mathrm{~h}$, and get bigger with the increase of the dealloying time. It should be noted that, in this work, the volume fraction of $\mathrm{Cu}_{2} \mathrm{O}$ particles on the surface is low (less than 20\%) and does not change much with the extension of etching time. Since the $\mathrm{Cu}_{2} \mathrm{O}$ crystals with different morphologies possess interesting physical, electrical and optical properties ${ }^{22-24}$, it is important to enhance the volume fraction of $\mathrm{Cu}_{2} \mathrm{O}$ particles on the glassy surface. Furthermore, metallic glasses are good carriers for $\mathrm{Cu}_{2} \mathrm{O}$ particles due to their high strength and high toughness. In the future, the as-prepared metallic glass/ $\mathrm{Cu}_{2} \mathrm{O}$ compounds with multiple properties are hopeful to be applied in broad fields.

\subsection{Dealloying in 1.2 $\mathrm{M} \mathrm{HCl}$ solution}

XRD patterns of the $\mathrm{Cu}_{52.5} \mathrm{Hf}_{40} \mathrm{Al}_{7.5}$ metallic glasses etched in $1.2 \mathrm{M}$ concentrated $\mathrm{HCl}$ solution open to air at 298 $\mathrm{K}$ for different time are shown in Figure 2. The diffraction pattern for the as-spun alloy (dealloying for $0 \mathrm{~h}$ ) exhibits a broad halo peak and has no Bragg peaks (Figure 2a), indicating a single homogeneous glassy structure. However, the broad peak disappears after dealloying for $12 \mathrm{~h}$ or longer time, which demonstrates that glassy structure is destroyed for the $\mathrm{Cu}_{52.5} \mathrm{Hf}_{40} \mathrm{Al}_{7.5}$ metallic glasses dealloyed in concentrated $\mathrm{HCl}$ solution for a long time. When dealloying for $12 \mathrm{~h}$, Figure $2 \mathrm{~b}$ reveals that only peaks matching with

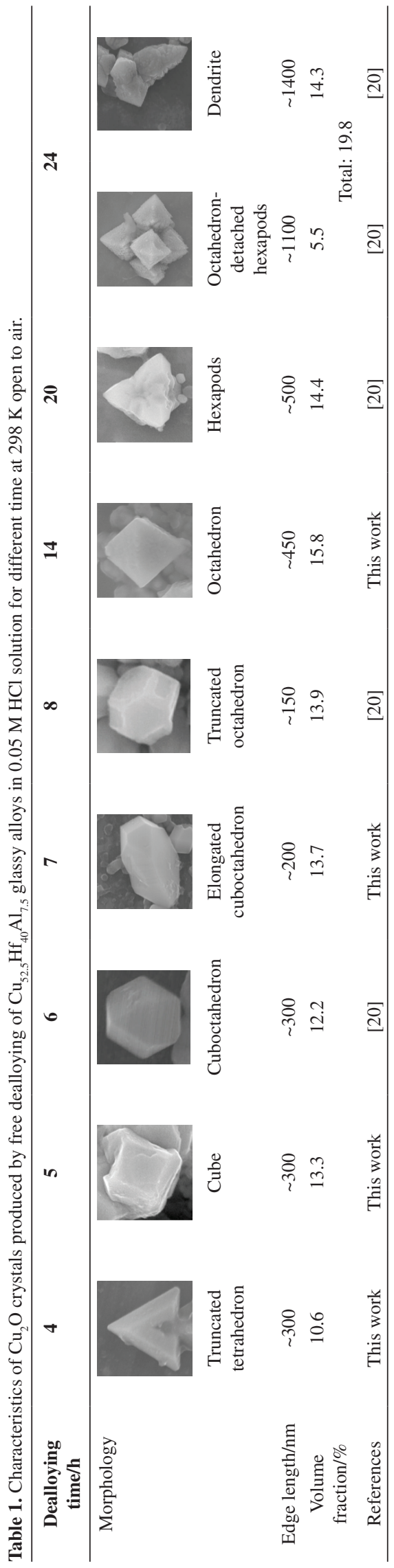




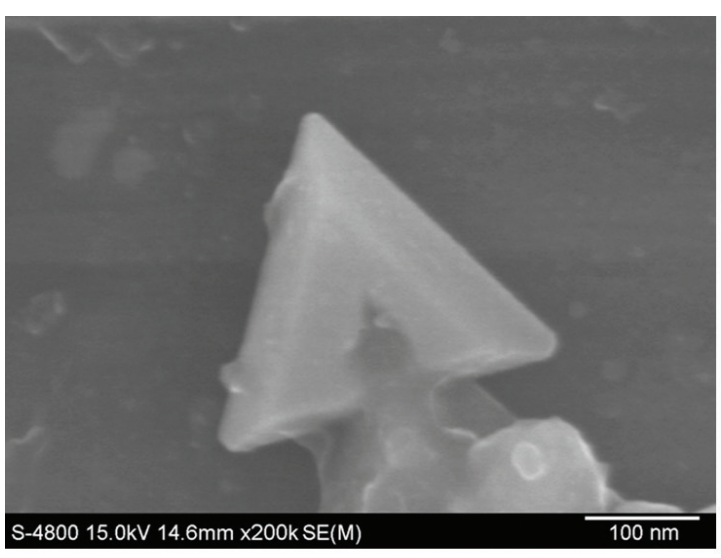

(a)

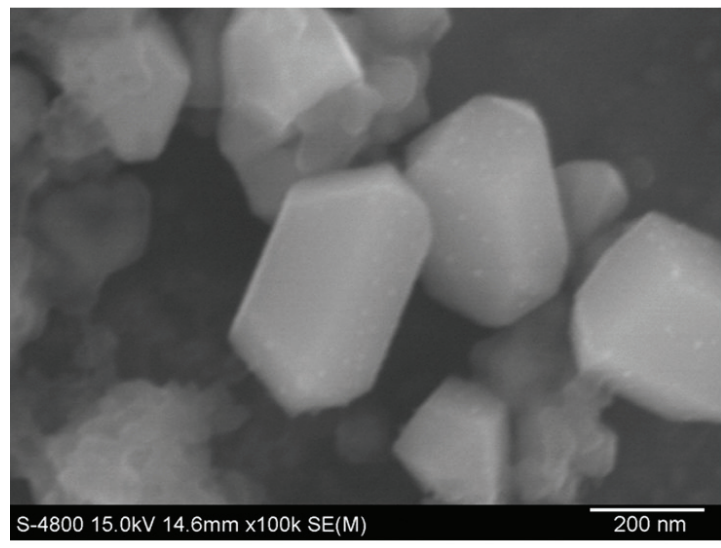

(c)

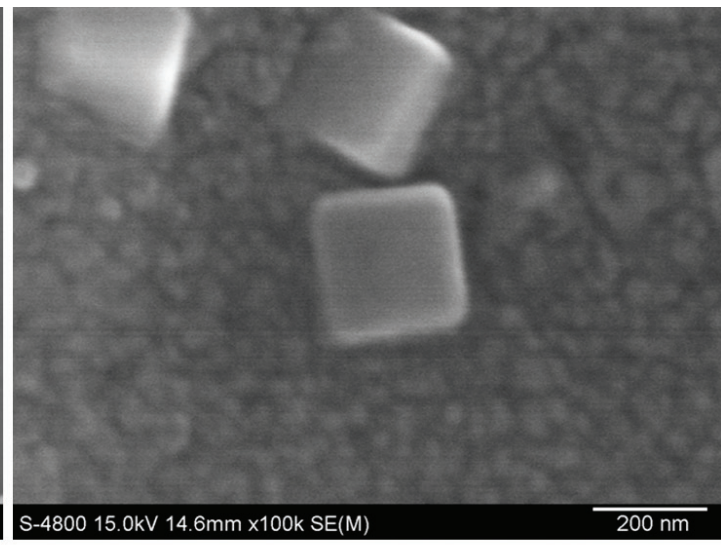

(b)

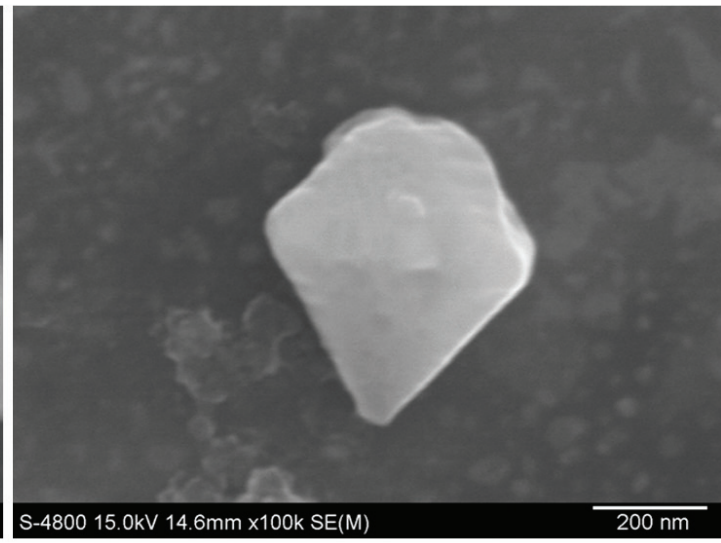

(d)

Figure 1. SEM images of the $\mathrm{Cu}_{52.5} \mathrm{Hf}_{40} \mathrm{Al}_{7.5}$ metallic glasses etched in $0.05 \mathrm{M} \mathrm{HCl}$ solution at $298 \mathrm{~K}$ for (a) $4 \mathrm{~h}$, (b) $5 \mathrm{~h}$, (c) $7 \mathrm{~h}$, (d) $14 \mathrm{~h}$.

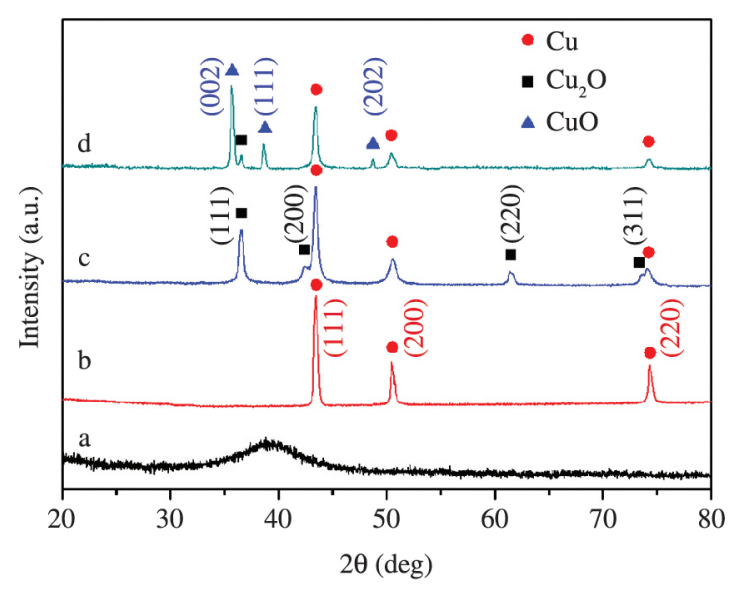

Figure 2. $\mathrm{XRD}$ patterns of the $\mathrm{Cu}_{52.5} \mathrm{Hf}_{40} \mathrm{Al}_{7.5}$ metallic glasses etched in $1.2 \mathrm{M} \mathrm{HCl}$ solution at $298 \mathrm{~K}$ for (a) $0 \mathrm{~h}$, (b) $12 \mathrm{~h}$, (c) $14 \mathrm{~h}$, (d) $18 \mathrm{~h}$.

fcc $\mathrm{Cu}$ (111), (200) and (220) (JCPDS number 04-0836) are obtained, and no peaks corresponding to $\mathrm{Hf}$ and $\mathrm{Al}$ elements are observed. The results indicate that the $\mathrm{Hf}$ and $\mathrm{Al}$ elements are removed from the alloy precursor, while the dealloying process is nearly complete. In addition, the crystal peaks in Figure 2c match with (111), (200), (220) and (311) crystal planes of $\mathrm{Cu}_{2} \mathrm{O}$ (JCPDS number 05-0667) besides (111), (200) and (220) crystal planes of $\mathrm{Cu}$. Thus, according to the increase of dealloying time from $12 \mathrm{~h}$ to $14 \mathrm{~h}$, respectively, the dealloying products change from $\mathrm{Cu}$ to $\mathrm{Cu}_{2} \mathrm{O} / \mathrm{Cu}$ compounds. Furthermore, after dealloying for $18 \mathrm{~h}$, it can be seen that (002), (111) and (202) crystal planes of $\mathrm{CuO}$ (JCPDS number 89-5899), (111) crystal planes of $\mathrm{Cu}_{2} \mathrm{O}$ and (111), (200) and (220) crystal planes of $\mathrm{Cu}$ can be identified from the XRD patterns shown in Figure $2 \mathrm{~d}$. Accordingly, the corrosion products with $\mathrm{CuO} / \mathrm{Cu}_{2} \mathrm{O} / \mathrm{Cu}$ mixture are made on the $\mathrm{Cu}_{52.5} \mathrm{Hf}_{40} \mathrm{Al}_{7.5}$ alloy surface after dealloying in $1.2 \mathrm{M}$ concentrated $\mathrm{HCl}$ solution for $18 \mathrm{~h}$. On the other hand, from Figure 2(b)-(d), we can also see that the relative intensity of $\mathrm{Cu}$ peak decreases with the increase of the dealloying time, indicating that the dealloying product $\mathrm{Cu}$ has gradually transformed to $\mathrm{Cu}_{2} \mathrm{O}$ and/or $\mathrm{CuO}$ during the dealloying.

SEM images of the $\mathrm{Cu}_{52.5} \mathrm{Hf}_{40} \mathrm{Al}_{7.5}$ metallic glasses etched in $1.2 \mathrm{M} \mathrm{HCl}$ solution for different time are shown in Figure 3. Considering XRD results, as shown in Figure $2 b$, it is interestingly found that a nanoporous $\mathrm{Cu}$ structure in Figure $3 \mathrm{a}$ is produced by the accumulation 


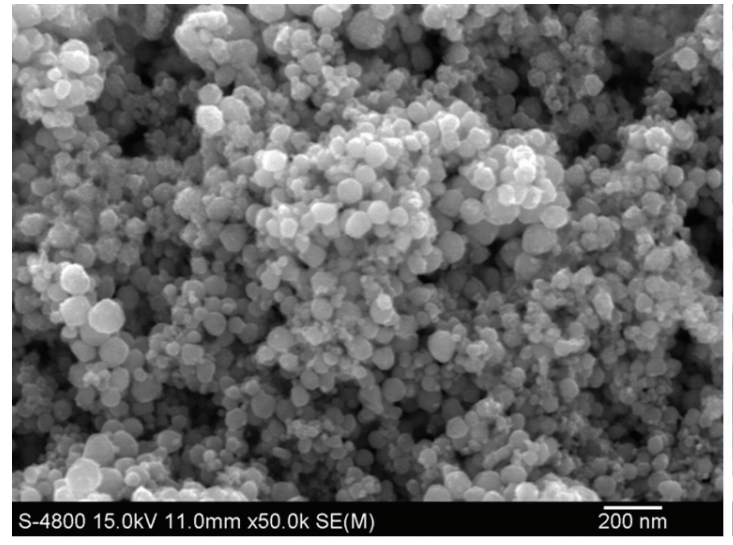

(a)

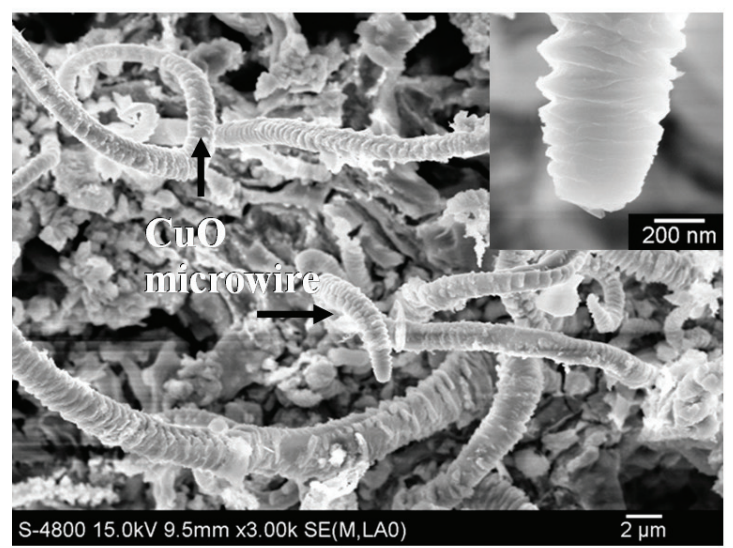

(c)

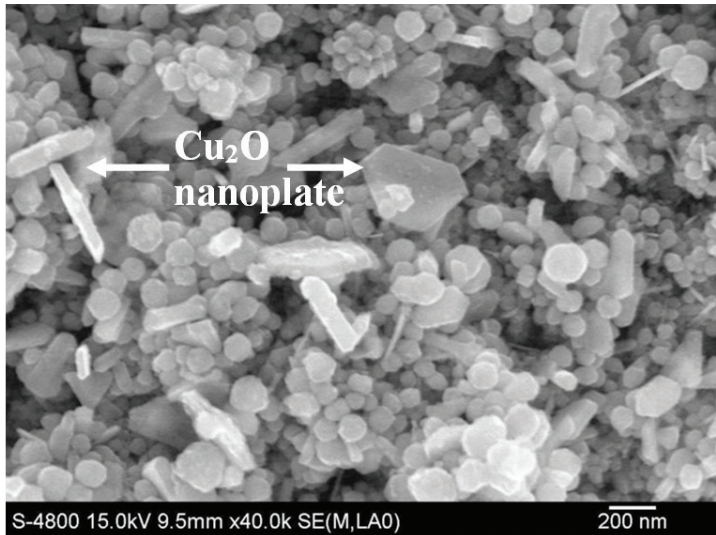

(b)

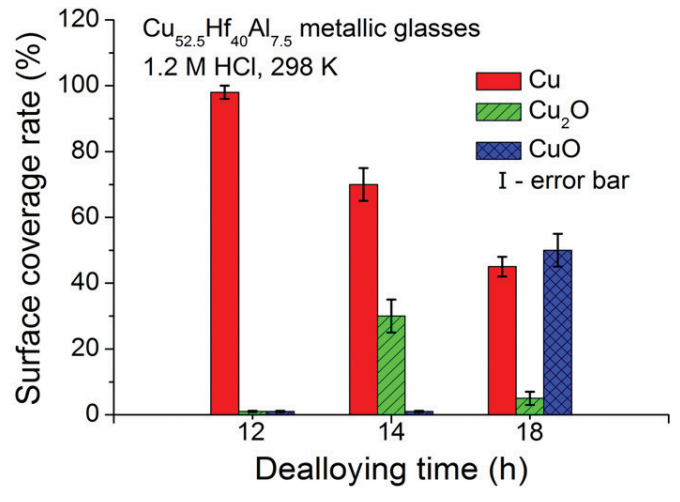

(d)

Figure 3. SEM images of the $\mathrm{Cu}_{525} \mathrm{Hf}_{40} \mathrm{Al}_{75}$ metallic glasses etched in $1.2 \mathrm{M} \mathrm{HCl}$ solution at $298 \mathrm{~K}$ for (a) $12 \mathrm{~h}$, (b) $14 \mathrm{~h}$, (c) $18 \mathrm{~h}$, the inset shows the microwire image at a higher magnification. (d) Surface coverage rate of different corrosion products with dealloying time.

of $\mathrm{Cu}$ nanospheres with diameter of $70-90 \mathrm{~nm}$ during the 12-hour dealloying. In this situation, a complete dealloying has finished, which results from relatively high concentration of $\mathrm{HCl}$ electrolytes and long time of etching $(12 \mathrm{~h})$. We should note that the as-produced nanoporous structure shown in Figure $3 \mathrm{a}$ is not the same as the widely studied bicontinuous nanoporous structure during dealloying ${ }^{25}$. The different dissolution behavior of constituent elements in dealloying electrolytes seems to be an important factor to influence the reorganized way of residual noble metal during the dealloying. There must be complicated reasons for determining the type of NPC, which would arouse an interesting topic for discussion.

When the dealloying time prolongs to $14 \mathrm{~h}$, as shown in Figure $3 \mathrm{~b}, \mathrm{Cu}_{2} \mathrm{O}$ nanoplates ${ }^{23}$ identified by XRD results (Figure 2c) with thickness of 80-90 nm are synthesized by spontaneous oxidation of $\mathrm{Cu}$ nanocrystals. With the further increase of the dealloying time $(18 \mathrm{~h}), \mathrm{CuO}$ microwires $^{26}$ with diameter of $\sim 2.5 \mu \mathrm{m}$ are observed in Figure 3c. As a result, designable dealloying products of $\mathrm{NPC}, \mathrm{Cu}_{2} \mathrm{O}$, and $\mathrm{CuO}$ with interesting morphologies can be tailored in $1.2 \mathrm{M}$ concentrated $\mathrm{HCl}$ electrolytes by controlling dealloying time. The surface coverage rate of different corrosion products with dealloying time is analyzed in Figure $3 \mathrm{~d}$, which reveals that $\mathrm{Cu}$ crystals could be oxidized into $\mathrm{Cu}_{2} \mathrm{O}$ and $\mathrm{CuO}$ with different ratio as the extension of the dealloying time. To our knowledge, it is the first time to fabricate $\mathrm{Cu}_{2} \mathrm{O}$ nanoplates and $\mathrm{CuO}$ microwires in the dealloying and spontaneous oxidation route. We are focusing on controlling the size and productivity of $\mathrm{Cu}_{2} \mathrm{O}$ and $\mathrm{CuO}$ by adjusting dealloying conditions. With the further development of the dealloying technology, the commercial producing method of $\mathrm{Cu}_{2} \mathrm{O}$ and $\mathrm{CuO}$ could be extended.

\subsection{Chemical process during dealloying}

Different kinds of dealloying products are made during etching $\mathrm{Cu}-\mathrm{Hf}-\mathrm{Al}$ metallic glasses in $\mathrm{HCl}$ solutions. A clear chemical process ${ }^{16} \mathrm{can}$ be summarized to explain the diverse types $\left(\mathrm{Cu}, \mathrm{Cu}_{2} \mathrm{O}\right.$ and $\left.\mathrm{CuO}\right)$ of these products:

$$
\begin{aligned}
& \mathrm{Cu}_{52.5} \mathrm{Hf}_{40} \mathrm{Al}_{7.5}+\mathrm{H}^{+} \rightarrow \mathrm{Cu}_{\text {(fresh) }}+\mathrm{Hf}^{4+}+\mathrm{Al}^{3+}+\mathrm{H}_{2} \\
& \mathrm{O}_{2 \text { (dissolve) }}=\mathrm{O}-\mathrm{O}_{\text {(adsorb) }} \\
& \mathrm{Cu}_{\text {(fresh) }}+2 \mathrm{H}^{+}=\mathrm{Cu}^{2+}+\mathrm{H}_{2} \\
& \mathrm{Cu}_{\text {(fresh) }}+\mathrm{Cu}^{2+}=2 \mathrm{Cu}^{+}
\end{aligned}
$$




$$
\begin{aligned}
& \mathrm{Cu}^{+}+\mathrm{O}-\mathrm{O}_{\text {(adsorb) }} \rightarrow \mathrm{Cu}_{2} \mathrm{O}+\mathrm{O}_{\text {(adsorb) }} \\
& \mathrm{Cu}_{2} \mathrm{O}+\mathrm{O}-\mathrm{O}_{\text {(adsorb) }} \rightarrow \mathrm{CuO}+\mathrm{O}_{\text {(adsorb) }}
\end{aligned}
$$

Once a Cu-Hf-Al glassy ribbon (Figure 4a) is immersed into $\mathrm{HCl}$ electrolytes, the $\mathrm{Hf}$ and $\mathrm{Al}$ elements are selectively etched, and fresh copper layer is subsequently formed on the surface of the sample (Equation 1 in Figure 4b). As we know, the depth of a dealloyed layer is determined by the dissolution rate of the glassy alloys in $\mathrm{HCl}$ solutions besides dealloying time. Usually, the $\mathrm{Cu}_{52.5} \mathrm{Hf}_{40} \mathrm{Al}_{7.5}$ glassy alloy presents very low dissolution rate in diluted $\mathrm{HCl}$ solution, whereas it shows enhanced dissolution rate in concentrated $\mathrm{HCl}$ solution. In this paper, Figure 1 shows the different particle structure formed on the surface of $\mathrm{Cu}-\mathrm{Hf}-\mathrm{Al}$ glassy substrate when etching in diluted $\mathrm{HCl}$ solution. On the other hand, Figure $3 \mathrm{a}$ exhibites typical $\mathrm{Cu}$ porous structure after dealloying in concentrated $\mathrm{HCl}$ solution, which implies that the constituent element $\mathrm{Hf}$ in the $\mathrm{Cu}-\mathrm{Hf}-\mathrm{Al}$ alloy shows more active chemical behavior in concentrated $\mathrm{HCl}$ solution.

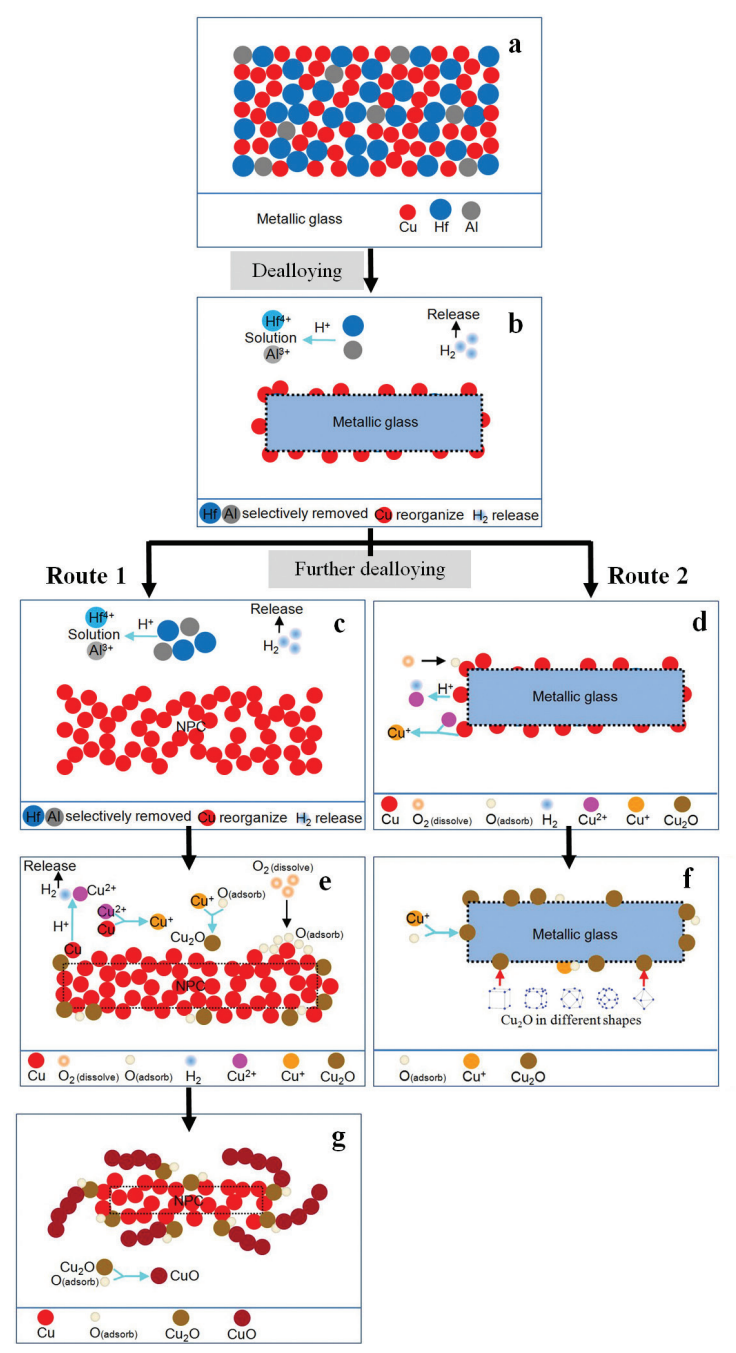

Figure 4. Scheme of the chemical dealloying progress of $\mathrm{Cu}-\mathrm{Hf}-\mathrm{Al}$ glassy alloys under different conditions.
Therefore, the dealloying process in diluted $\mathrm{HCl}$ solution might be retarded by the slow dissolution of $\mathrm{Hf}^{4+}$ cations or increase of $\mathrm{pH}$ value. So, the chemical dealloying process of the $\mathrm{Cu}-\mathrm{Hf}-\mathrm{Al}$ metallic glasses are different between in diluted and concentrated $\mathrm{HCl}$ solutions, and can be classified into two routes.

A complete dealloying happens when dealloying in concentrated $\mathrm{HCl}$ electrolytes in Figure 4c (Route 1). As a result, the porous structures are formed at the initial stage of the chemical reaction. However, a superficial dealloying happens when dealloying in diluted $\mathrm{HCl}$ electrolytes in Figure 4d (Route 2). In this situation, the glassy structures are retained. With the increase of the dealloying time, the Route 1 and Route 2 will further proceed. The oxygen dissolved in the electrolyte is strongly adsorbed on the fresh copper surface (Equation 2). At the same time, part of the fresh $\mathrm{Cu}$ dissolves into the acid solutions to form $\mathrm{Cu}^{2+}$ cations, acompanying with $\mathrm{H}_{2}$ release (Equation 3 ). It seems that it would be easier to form $\mathrm{CuO}$ rather than $\mathrm{Cu}_{2} \mathrm{O}$ by the reaction of $\mathrm{Cu}^{2+}$ cations and adsorbed oxygen. Actually, the $\mathrm{Cu}^{+}$cations will be preferentially obtained from a disproportionation reaction between fresh $\mathrm{Cu}$ and $\mathrm{Cu}^{2+}$ cations (Equation 4). These $\mathrm{Cu}^{+}$cations soon react with adsorbed oxygen. As a result, $\mathrm{Cu}_{2} \mathrm{O}$ in different shapes are fabricated and heaped up (Equation 5). The creation of $\mathrm{Cu}_{2} \mathrm{O}$ during dealloying, which have been reported by other studies ${ }^{16,20}$, further confirms the occurrence of the disproportionation reaction in Equation 4. According to different reaction conditions, $\mathrm{Cu}$ nanospheres/ $\mathrm{Cu}_{2} \mathrm{O}$ nanoplates compounds created in Figure $3 \mathrm{~b}$ are corresponding to Figure 4e in Route 1, while Figure 4f in Route 2 illustrates the formation of the metallic glass $/ \mathrm{Cu}_{2} \mathrm{O}$ particles in different morphologies (as shown in Figure 1 and Table 1). The key factor for forming $\mathrm{Cu}_{2} \mathrm{O}$ crystals with different shapes can be attributed to the value of $R^{[22]}$, which represents the growth rate of $\mathrm{Cu}_{2} \mathrm{O}$ particles along the $<100>$ direction relative to that of the $<111>$ direction. In this situation, the content (time dependent) of adsorbed oxygen with $\mathrm{Cu}^{+}$cations strongly influence the value of $R$. As a result, $\mathrm{Cu}_{2} \mathrm{O}$ crystals with designable shapes can be tailored by controlling dealloying time, as shown in Table 1 and Figure 4f.

Moreover, with the further increase of the dealloying time, $\mathrm{Cu}_{2} \mathrm{O}$ is oxidized by adsorbed oxygen on the surface and change to $\mathrm{CuO}$ microwires (Equation 6 in Figure $4 \mathrm{~g}$ ). In summary, due to a big difference of examined $\mathrm{Cu}-\mathrm{Hf}-\mathrm{Al}$ alloys in the electrolyte concentration and dealloying time, one or mixed dealloying products $\left(\mathrm{Cu}, \mathrm{Cu}_{2} \mathrm{O}\right.$ and $\left.\mathrm{CuO}\right)$, which depend on above chemical process, will finally be produced.

As we know, both $\mathrm{Cu}_{2} \mathrm{O}$ and $\mathrm{CuO}$ are p-type semiconductors. $\mathrm{Cu}_{2} \mathrm{O}$ have potential applications in gas sensors, solar energy conversion, lithium ion batteries, photocatalysts and so on ${ }^{27-30}$. $\mathrm{CuO}$ is known for its applications in optical switches, field emitters, gas sensors, Li-ion battery anode materials, and chemical conversion catalysts ${ }^{31,32}$. Hence, $\mathrm{Cu}_{2} \mathrm{O}$ and $\mathrm{CuO}$ particles with different size and morphologies are highly desirable for wide applications. In traditional chemical method, they are synthesized and stored in liquid solutions. By using 
a dealloying process, however, they can be fabricated on solid ribbon and easily stored or extracted from drying oven. According to different application requirement, amorphous $/ \mathrm{Cu}_{\mathrm{x}} \mathrm{O}^{20,21}$ composites and porous $\mathrm{Cu} / \mathrm{Cu}_{\mathrm{x}} \mathrm{O}(\mathrm{x}=1$, 2) composites can be synthesized and tailored by controlling dealloying conditions and choosing different dealloying routes (Figure 4). More detailed studies about applications in various fields of these dealloying products need to be done in the future.

\section{Conclusions}

In this work, controllable corrosion products are designed by free dealloying $\mathrm{Cu}-\mathrm{Hf}-\mathrm{Al}$ metallic glasses using different technique parameters. The concentration of electrolytes and dealloying time strongly influence the type of dealloying products. A superficial dealloying happens when dealloying in diluted $\mathrm{HCl}$ electrolytes. Regular $\mathrm{Cu}_{2} \mathrm{O}$ microparticles with designable morphology can be tailored in $0.05 \mathrm{M} \mathrm{HCl}$ solutions by controlling dealloying

\section{References}

1. Farkas D, Caro A, Bringa E and Crowson D. Mechanical response of nanoporous gold. Acta Materialia. 2013; 61:32493256. http://dx.doi.org/10.1016/j.actamat.2013.02.013

2. Qiu HJ, Kang JL, Liu P, Hirata A, Fujita T and Chen MW. Fabrication of large-scale nanoporous nickel with a tunable pore size for energy storage. Journal of Power Sources. 2014; 247:896-905. http://dx.doi.org/10.1016/j. jpowsour.2013.08.070

3. Dan ZH, Qin FX, Sugawara Y, Muto I and Hara N. Elaboration of nanoporous copper by modifying surface diffusivity by the minor addition of gold. Microporous and Mesoporous Materials. 2013; 165:257-264. http://dx.doi.org/10.1016/j. micromeso.2012.08.026

4. Wang XG, Tang B, Huang XB, Ma Y and Zhang ZH. High activity of novel nanoporous $\mathrm{Pd}-\mathrm{Au}$ catalyst for methanol electro-oxidation in alkaline media. Journal of Alloys and Compounds. 2013; 565:120-126. http://dx.doi.org/10.1016/j. jallcom.2013.02.170

5. Jia FL, Zhao JH and Yu XX. Nanoporous $\mathrm{Cu}$ film/Cu plate with superior catalytic performance toward electro-oxidation of hydrazine. Journal of Power Sources. 2013; 222:135-139. http://dx.doi.org/10.1016/j.jpowsour.2012.08.076

6. Tang Y, Tang B, Qing JB, Li Q and Lu LS. Nanoporous metallic surface: Facile fabrication and enhancement of boiling heat transfer. Applied Surface Science. 2012; 258:8747-8751. http:// dx.doi.org/10.1016/j.apsusc.2012.05.085

7. Detsi E, Sellès MS, Onck PR and Hosson JTMD. Nanoporous silver as electrochemical actuator. Scripta Materialia. 2013; 69:195-198. http://dx.doi.org/10.1016/j. scriptamat.2013.04.003

8. Kang JL, Hirata A, Kang LJ, Zhang XM, Hou Y, Chen LY et al. Enhanced supercapacitor performance of $\mathrm{MnO}_{2}$ by atomic doping. Angewandte Chemie. 2013; 125:1708-1711. http:// dx.doi.org/10.1002/ange.201208993

9. Su LS and Gan YX. Nanoporous Ag and Ag-Sn anodes for energy conversion in photochemical fuel cells. Nano Energy. 2012; 1:159-163. http://dx.doi.org/10.1016/j. nanoen.2011.08.002 time. A complete dealloying take place when dealloying in concentrated $\mathrm{HCl}$ electrolytes. Designable products of NPC, $\mathrm{Cu}_{2} \mathrm{O}$, and $\mathrm{CuO}$ with interesting morphologies are tailored in $1.2 \mathrm{M} \mathrm{HCl}$ electrolytes with different dealloying time. A clear chemical process during dealloying is summarized, which guides for designing different useful dealloying products. Due to a big difference of examined $\mathrm{Cu}-\mathrm{Hf}-\mathrm{Al}$ alloys in the electrolyte concentration and dealloying time, one or mixed dealloying products $\left(\mathrm{Cu}, \mathrm{Cu}_{2} \mathrm{O}\right.$ and $\left.\mathrm{CuO}\right)$, which depend on the progress of relative chemical reactions and the different dealloying route, will finally be produced.

\section{Acknowledgments}

This work was financially supported by the " 100 Talents Project" of Hebei Province, China (E2012100009), the National High Technology Research and Development Program (863 Program) of China (2013AA031002) and the Natural Science Foundation of Hebei Province, China (E2012202017).

10. Wittstock A, Biener J and Bäumera M. Nanoporous gold: a new material for catalytic and sensor applications. Physical Chemistry Chemical Physics. 2010; 12:12919-12930. http:// dx.doi.org/10.1039/c0cp00757a

11. Bringa EM, Monk JD, Caro A, Misra A, Zepeda-Ruiz L, Duchaineau $\mathrm{M}$ et al. Are nanoporous materials radiation resistant? Nano Letters. 2012; 12:3351-3355. http://dx.doi. org/10.1021/nl201383u

12. Xu CX, Wang RY, Zhang Y and Ding Y. A general corrosion route to nanostructured metal oxides. Nanoscale. 2010; 2:906909. http://dx.doi.org/10.1039/b9nr00351g

13. Xu CX, Liu YQ, Zhou C, Wang L, Geng HR and Ding Y. An in situ dealloying and oxidation route to $\mathrm{Co}_{3} \mathrm{O}_{4}$ nanosheets and their ambient-temperature $\mathrm{CO}$ oxidation activity. ChemCatChem. 2011; 3:399-407. http://dx.doi.org/10.1002/ cctc. 201000275

14. Hao Q, Li MH, Jia SZ, Zhao XY and Xu CX. Controllable preparation of $\mathrm{Co}_{3} \mathrm{O}_{4}$ nanosheets and their electrochemical performance for Li-ion batteries. RSC Advances. 2013; 3:78507854. http://dx.doi.org/10.1039/c3ra23448g

15. Erlebacher J and Sieradzki K. Pattern formation during dealloying. Scripta Materialia. 2003; 49:991-996. http://dx.doi. org/10.1016/S1359-6462(03)00471-8

16. Chen LY, Yu JS, Fujita T and Chen MW. Nanoporous copper with tunable nanoporosity for SERS applications. Advanced Functional Materials. 2009; 19:1221-1226. http://dx.doi. org/10.1002/adfm.200801239

17. Li M, Zhou YZ and Geng HR. Fabrication of nanoporous copper ribbons by dealloying of Al-Cu alloys. Journal of Porous Materials. 2012; 19:791-796. http://dx.doi.org/10.1007/ s10934-011-9532-3

18. Hayes JR, Hodge AM, Biener J, Hamza AV and Sieradzki K. Monolithic nanoporous copper by dealloying Mn-Cu. Journal of Materials Research. 2006; 21:2611-2616. http://dx.doi. org/10.1557/JMR.2006.0322

19. Zhao CC, Qi Z, Wang XG and Zhang ZH. Fabrication and characterization of monolithic nanoporous copper through chemical dealloying of $\mathrm{Mg}-\mathrm{Cu}$ alloys. Corrosion Science. 2009; 51:2120-2125. http://dx.doi.org/10.1016/j. corsci.2009.05.043 
20. Wang ZF, Qin CL, Zhao WM and Jia JQ. Tunable $\mathrm{Cu}_{2} \mathrm{O}$ nanocrystals fabricated by free dealloying of amorphous ribbons. Journal of Nanomaterials. 2012; Article ID 126715. http://dx.doi.org/10.1155/2012/126715

21. Wang ZF, Qin CL, Liu L, Wang LJ, Ding J and Zhao WM. Synthesis of $\mathrm{Cu}_{\mathrm{x}} \mathrm{O}(\mathrm{x}=1,2) /$ amorphous compounds by dealloying and spontaneous oxidation method. Materials Research. 2014; 17(1):33-37. http://dx.doi.org/10.1590/S151614392013005000155.

22. Xu JS and Xue DF. Five branching growth patterns in the cubic crystal system: A direct observation of cuprous oxide microcrystals. Acta Materialia. 2007; 55:2397-2406. http:// dx.doi.org/10.1016/j.actamat.2006.11.032

23. Kuo $\mathrm{CH}$ and Huang $\mathrm{MH}$. Morphologically controlled synthesis of $\mathrm{Cu}_{2} \mathrm{O}$ nanocrystals and their properties. Nano Today. 2010; 5:106-116. http://dx.doi.org/10.1016/j. nantod.2010.02.001

24. Zhu QW, Zhang YH, Wang JJ, Zhou FS and Chu PK. Microwave synthesis of cuprous oxide micro-/nanocrystals with different morphologies and photocatalytic activities. Journal of Materials Science \& Technology. 2011; 27:289-295. http://dx.doi.org/10.1016/S1005-0302(11)60064-9

25. Dan ZH, Qin FX, Sugawara Y, Muto I, Makino A and Hara N. Nickel-stabilized nanoporous copper fabricated from ternary TiCuNi amorphous alloys. Materials Letters. 2013; 94:128131. http://dx.doi.org/10.1016/j.matlet.2012.12.028

26. Kim DK, Bae JH, Kang MK and Kim HJ. Analysis on thermite reactions of $\mathrm{CuO}$ nanowires and nanopowders coated with $\mathrm{Al}$.
Current Applied Physics. 2011; 11:1067-1070. http://dx.doi. org/10.1016/j.cap.2011.01.043

27. Zhang JT, Liu JF, Peng Q, Wang X and Li YD. Nearly monodisperse $\mathrm{Cu}_{2} \mathrm{O}$ and $\mathrm{CuO}$ nanospheres: preparation and applications for sensitive gas sensors. Chemistry of Materials. 2006; 18:867-871. http://dx.doi.org/10.1021/ cm052256f

28. Mahalingam T, Chitra J, Ravi G, Chu J and Sebastian P. Characterization of pulse plated $\mathrm{Cu}_{2} \mathrm{O}$ thin films. Surface \& Coatings Technology. 2003; 168:111-114. http://dx.doi. org/10.1016/S0257-8972(03)00211-1

29. Poizoy P, Laruelle S, Grugeon S, Dupont L and Trascon J. Nano-sized transition-metal oxides as negative-electrode materials for lithium-ion batteries. Nature. 2000; 407:496-499. PMid:11028997. http://dx.doi.org/10.1038/35035045

30. Kumar R, Mastai Y, Diamant Y and Gedanken A. Sonochemical synthesis of amorphous $\mathrm{Cu}$ and nanocrystalline $\mathrm{Cu}_{2} \mathrm{O}$ embedded in a polyaniline matrix. Journal of Materials Chemistry. 2001; 11:1209-1213. http://dx.doi.org/10.1039/ b005769j

31. Jiang XC, Herricks $\mathrm{T}$ and $\mathrm{Xia} \mathrm{YN}$. CuO nanowires can be synthesized by heating copper substrates in air. Nano Letters. 2002; 2:1333-1338. http://dx.doi.org/10.1021/ n10257519

32. Grugeon S, Laruelle S, Herrera-Urbina R, Dupont L, Poizot $\mathrm{P}$ and Tarascon J. Particle size effects on the electrochemical performance of copper oxides toward lithium. Journal of The Electrochemical Society. 2001; 148:A285-A292. http://dx.doi. org/10.1149/1.1353566 